\title{
LITERATURA
}

Couroyer B., Le temple de Yaho et l'orientation dans les papyrus araméens d'Elephantine, RB 68/1961/524-540; C ow le y A. E., Aramaic Papyri of the Fifth Century B. C., Oxford 1923; Gord on C. H., The Origin of the Jews in Elephantine, JNES 14(1955)56-58; G r el ot P., Etudes sur le „Papyrus pascal” d'Elephantine, VT 4 (1954)349-384; t e nże, Documents araméens d'Egypte, Paris 1972; K raeling E. G., The Brooklyn Museum Aramaic Papyri, New Haven 1953; V in cent A., La religion des judéo-araméens d'Elephantine, Paris 1937.

\section{POWSTANIE TOWARZYSTWA BIBLIJNEGO W POLSCE}

Dnia 24 listopada 1992 roku ukonstytuowało się w Warszawie Towarzystwo Biblijne $\mathrm{w}$ Polsce, które jest kontynuacją i następcą prawnym Brytyjskiego i Zagranicznego Towarzystwa Biblijnego, działającego w naszym kraju od 1816 roku. Nowo powstałe Towarzystwo jest organizacją międzykościelną i niedochodową. Jako organizacja ekumeniczna współpracuje ze wszystkimi Kościołami i Związkami wyznaniowymi w Polsce, oraz krajowymi Towarzystwami Biblijnymi na całym świecie. Jest członkiem Zjednoczonych Towarzystw Biblijnych z siedziba $w$ Wielkiej Brytanii. Celem działalności Towarzystwa Biblijnego jest tłumaczenie Pisma Swiętego na język polski i inne języki, drukowanie i rozpowszechnianie Biblii po najniższej cenie, oraz przyczynianie się do znajomości tekstów biblijnych.

W pierwszym posiedzeniu konstytucyjnym Towarzystwa wzięli udział przedstawiciele $\mathrm{z}$ Kościoła Rzymskokatolickiego, Polskiego Autokefalicznego Kościoła Prawosławnego, Kościoła Ewangelicko-Augsburskiego, Kościoła Polskokatolickiego, Kościoła Ewangelicko-Reformowanego, Kościoła Starokatolickiego Mariawitów, Kościoła Ewangelicko-Metodystycznego, Kościoła Chrześcijan Baptystów, Kościoła Adwentystów Dnia Siódmego i Chrześcijańskiej Społeczności.

Obrady otworzyła i słowo wprowadzające wygłosiła dyrektor Barbara Enholc-Narzyńska. Następnie uczestnicy zebrania uchwalili statut Towarzystwa i dokonali wyboru Komitetu Krajowego, jego Prezydium oraz Komisji Rewizyjnej.

Przewodniczącym Komitetu Krajowego i Prezydium zostal ks. prof. dr hab. Witold Benedyktowicz z Kościoła Ewangelicko-Metodystycznego $\mathrm{w}$ Polsce, zastępcp przewodniczącego wybrano ks. mgr Jerzego Banaka z Kościoła Rzymskokatolickiego, skarbnikiem ks. mgr. prot. Mikołaja Lenczewskiego jun. z Polskiego Autokefalicznego Kościoła Prawosławnego.

W skład Komisji Rewizyjnej weszli: ks. prof. dr hab. Zachariasz Łyko (Przewodniczący) z Kościoła Adwentystów Dnia Siódmego w R.P., ks. doc. Edward Bałakier z Kościoła Polskokatolickiego w R.P., ks. mgr Waldemar Preiss z Kościoła Ewangelicko-Augsburskiego w R.P.

Sekretarzem Zebrania Konstytucyjnego był prezbiter Krystian Ber z Kościoła Chrześcijan Baptystów.

Komitet Krajowy zatwierdzil mgr Barbarę Enholc-Narzyńską na stanowisku Dyrektora Generalnego Towarzystwa Biblijnego w Polsce. Godnośc patronów Towarzystwa Komitet Krajowy nadał: Metropolicie Bazy- 
lemu Doroszkiewiczowi, Metropolicie Warszawskiemu i Całej Polski oraz Biskupowi dr Januszowi Narzyńskiemu z Kościoła Ewangelicko-Augsburskiego w R.P., którzy byli wnioskodawcami prawnej legalizacji Towarzystwa w dniu 11 grudnia 1990 roku.

Nowo powstałemu Towarzystwu Biblijnemu „Ruch Biblijny i Liturgiczny" składa najlepsze życzenia! „Słowo Twe, Panie, trwa na wieki” (Ps 119, 89).

\section{WS POM I EN I A P O Ś M I E R T N E}

\section{Ks. Antoni Dreja}

\section{ŚP. KS. KONRAD MARKLOWSKI (1912-1990)}

Ks. Konrad Marklowski, syn Edwarda kowala i Martyny z d. Witt, urodził się 17 lutego 1912 w Królewskiej Hucie (dzisiaj Chorzów). Miał czworo rodzeństwa. Ochrzczony został w kościele parafialnym św. Józefa, gdzie też przystąpił do I spowiedzi i Komunii św. W rodzinnym mieście uczęszczał do szkoły powszechnej, najpierw niemieckiej (przez 5 lat), potem polskiej. W latach 1924-1932 uczęszczał do Państwowego Gimnazjum Klasycznego w Królewskiej Hucie. Egzamin dojrzałości zdał 20 maja 1932. Proboszcz i katecheta w swej opinii do Seminarium stwierdzają, że był najlepszym maturzystą. Potwierdza to świadectwo dojrzałości: poza jedną oceną dobry (fizyka), wszystkie pozostałe oceny bardzo dobry.

12 czerwca 1932 zgłosił się do Sląskiego Seminarium Duchownego w Krakowie i w roku akad. 1932/33 rozpoczął studia teologiczne na Uniwersytecie Jagiellońskim. W czasie pięcioletnich studiów słuchał m. in. wykładów następujących profesorów: A. Archutowskiego, J. Kaczmarczyka, M. Godlewskiego, K. i M. Michalskich, T. Glemmy i M. Morawskiego. $\mathrm{Z}$ historii i nauk związanych $\mathrm{z}$ Pismem świętym otrzymywał najwyższe oceny. Zgodnie ze swoimi zainteresowaniami biblijnymi uczył się na Uniwersytecie języków orientalnych: hebrajskiego, aramejskiego, syryjskiego i arabskiego. Z Gimnazjum wyniósł znajomość języków klasycznych łacińskiego i greckiego oraz nowożytnych: niemieckiego, francuskigo i włoskiego. W czasie studiów na Uniwersytecie kontynuował naukę j. włoskiego. Brał udział w seminarium Pisma świętego (Archutowski) i teologii moralnej (Wicher). W r. akad. 1936/37 otrzymał nagrodę pieniężną Uniwersytetu.

W grudniu 1936 przyjął święcenia subdiakonatu, a 20 czerwca 1937 w Katowicach święcenia kapłańskie z rąk Ks. Biskupa S. Adamskiego. Za pracę: „Aspiracje mesjańskie w Babilonii i w Egipcie a mesjanizm izraelski" otrzymał 14 maja 1937 tytuł magistra teologii w Wydz. Teol. UJ.

Po święceniach został mianowany wikariuszem w Czarnym Lesie (dzielnica Nowego Bytomia) a w sierpniu 1939 został zamianowany katechetą 